\title{
ÜVEGHULLADÉK ELŐKÉSZÍTÉSI TECHNOLÓGIA A KÖRKÖRÖS GAZDASÁG JEGYÉBEN
}

\author{
Voith Katalin \\ tudományos fömunkatárs, Miskolci Egyetem, Energetikai és Vegyipari Gépészeti Intézet \\ 3515 Miskolc, Miskolc-Egyetemváros, e-mail: gkdh12@uni-miskolc.hu
}

\begin{abstract}
Absztrakt
A háztartásokban keletkezett csomagolási üveghulladék 100 \%-ban újrahasznositható. Ez fontos tény, mivel az Európai Unió 2018/852/EU csomagolási irányelve alapján minden tagországnak törekednie kell arra, hogy megelözzék a csomagolási hulladék gyártását. Ezen túlmenöen a hangsúlyt a csomagolási hulladék újrafelhasználására, újrafeldolgozására kell helyezni. Megakadályozva ezzel a csomagolási hulladék végleges ártalmatlanitását, azaz megtörténik a körkörös gazdaságra való áttérés. A körkörös gazdaság olyan gazdaság, amely minimalizálja az eröforrások, hulladékok, kibocsátások és az energia elszivárgását. Ez tartós tervezés, karbantartás, javitás, újrafelhasználás és újrahasznositás révén érhetö el. Az EU 2018/852/EU irányelvének célkitüzése, hogy 2025. december 31-ig az üveg csomagolási hulladéknak 70 \%-át dolgozzák fel újra. Ez a szám 2030-ra 75 \%-ra kell megemelkedjen. A témaválasztás fö oka ez az EU-s célkitüzés. A cikk az üveg csomagolási hulladék környezetszempontú elökészitési folyamatának technológiatervezését tekinti át.
\end{abstract}

Kulcsszavak: csomagolási üveghulladék, újrafeldolgozási technológia, életciklus szemlélet, körkörös gazdaság

\begin{abstract}
The domestic packaging glass waste is recyclable in $100 \%$. This is a very important fact since according to the directive (EU) no. 2018/852 of the European Parliament and of The Council of 30 May 2018 all member countries must eliminate the production of packaging waste. Beyond this goal the emphasis has to be on the recycling and reusing of packaging waste. This would put an end on the final disposal of packaging waste and in this way the change to the circular economy would happen. With a working circular economy the emission of waste materials and the leakage of energy is can be minimalized, that can be reached by sustainable planning, maintenance, correction, reusing and recycling. The EU Directive 2018/852 / EU aims to recycle 70\% of glass packaging waste by 31 December 2025. This figure should rise to $75 \%$ by 2030. The main reason for the choice of this topic is this EU objective. This article is an overview of the environmentally-friendly, technology design of the preparation process of domestic glass waste.
\end{abstract}

Keywords: packaging glass waste, recycling process, life cycle approach, circular economy 


\section{Bevezetés}

Napjaink egyik legégetőbb problémáját a hulladék okozza. Fogyasztói társadalmunk arra ösztönözi, kényszeríti a magánembereket és cégeket, hogy eszközeiket, berendezéseiket folyamatosan cseréljék újabbra, függetlenül attól, hogy a régi még müködő képes-e és ellátja-e a feladatát vagy sem.

Szerencsére az elmúlt évtizedekben egyre inkább megnövekedett a figyelem a környezetvédelem iránt. Ide tartozik a termékekkel összefüggö lehetséges hatások iránti figyelem is, ami arra ösztönözi a tudósokat, mérnököket, hogy ebbe az irányban fejlesszék a technológiákat és módszereket. Szükséges, hogy egyre jobban megértsük ezek hatásait és azokat irányítani tudjuk.

A mai ember és gazdaság életében kulcsfontosságúvá kell váljon, hogy tisztában legyen azzal, mi a hulladék és mit lehet tenni a kisebb mennyiség keletkezése érdekében. A hulladék az ember mindennapi élete, munkája, gazdasági tevékenysége során keletkező, a keletkezés helyén feleslegessé vált, ott közvetlenül fel nem használható, különböző minőségü és halmazállapotú anyag, termék, maradvány, tárgy, leválasztott szennyezőanyag, szennyezett kitermelt föld, amelyet tulajdonosuk sem közvetlenül felhasználni, sem értékesíteni nem tud és amelynek kezeléséről külön kell gondoskodni. A hulladékokat leggyakrabban az eredet szerinti csoportosítjuk. Így beszélhetünk termelési (ipari, mezőgazdasági, szolgáltatási) vagy települési (kommunális) hulladékról. A szilárd települési hulladékok egyik leggyorsabban növekvő szegmensét a csomagolási hulladék jelenti. Az Európai Unióban kiemelten kezelik a csomagolás és a csomagolási hulladékok újrahasznosítási követelményeit, amelynek kötelező mértékét irányelvekben határozzák meg.

Ebben a kutatói tanulmányban a háztartásokban keletkezett üveghulladék kerül a középpontba. Ennek több oka is van. Elsődlegesen az, hogy a háztartásokban keletkezett csomagolási üveghulladék (ide értjük, a beföttesüvegeket, különbözö üdítős, sörös, boros, pezsgős és egyéb italos üvegeket, az étkezési olajok üvegeit stb.) gyakorlatilag 100 \%-ban újrahasznosítható. Az üveg anyagában hasznosítható csomagolási hulladék, mely anyagáramra egyik hazai kötelezettségünk, hogy az idei évvel bezárólag legalább 55\%-os hányadában szükséges anyagában hasznosítanunk az üveg hulladékok minimum 50 tömegszázalékos visszagyüjtése mellett. Az Európai Parlament és a Tanács (EU) 2018/852 irányelve alapján - ami módosítja a 94/62/EK irányelveit - minden tagországnak törekednie kell arra, hogy megelőzzék a csomagolási hulladék gyártását. Ezen túlmenően a hangsúlyt a csomagolási hulladék elsősorban anyagában történő hasznosítására és újrafeldolgozására kell helyezni, megakadályozva ezzel a csomagolási hulladék végleges ártalmatlanítását. A csomagolási hulladék gyártásának megszüntetése és újrafeldolgozásának ösztönzése mellett, a 2018/852 irányelv további célkitüzése, hogy 2025 december 31-ig az üveg csomagolási hulladéknak 70 \%-át dolgozzák fel újra. Ez a szám 2030-ra 75 \%-ra kell megemelkedjen. Ily módon hozzájárulhatunk a körkörös gazdaságra való áttérésre. A körkörös gazdaság olyan gazdaság, amely minimalizálja az erőforrások, hulladékok, kibocsátások és az energia elszivárgását. Ez tartós tervezés, karbantartás, javítás, újrafelhasználás és újrahasznosítás révén érhető el [1].

A csomagolásról és a csomagolási hulladékkal kapcsolatos hulladékgazdálkodási tevékenységekröl szóló 442/2012. (XII. 29.) Korm. rendelet az 534/2013. (XII. 30.) Korm. rendelettel módosul, 2013. december 31. napjától. A 2013-ban életbe lépő, hulladékokról szóló törvény egyik elsődleges célja az volt, hogy bevezesse a lakosság körében azt a szemléletet, hogy minél kevesebb háztartásból kikerülö hulladék kerüljön a szeméttelepre lerakásra, rászoktassa a szelektív hulladékgyüjtésre. A 2017. évi CXXXI. törvény (a környezetvédelmi termékdíjról szóló 2011. évi LXXXV. törvény módosításáról) alapján az üvegre vonatkozó termékdíjtétel $19 \mathrm{Ft} / \mathrm{kg}$, a felső hasznosítási arány $65 \%$, az országos átla- 
gos teljesítési hányad 60\% és a fajlagos kezelési alapköltség $10 \mathrm{Ft} / \mathrm{kg}$. A témaválasztás másik fő oka a fentiekben említett EU célkitüzés [2].

Mint jogszabályi háttér meg kell említeni a 2012. évi CLXXXV. törvényt, amelyet az Országgyülés a környezet és az emberi egészség védelme érdekében hozott. Célja a környezetterhelés mérséklése, a természeti erőforrásokkal való takarékos gazdálkodás, az erőforrás-felhasználás hatásainak csökkentése, hatékonyságának javítása, továbbá a hulladékképződés, illetve a képződő hulladék káros hatásainak megelőzése, mennyiségének és veszélyességének csökkentése. Előtérbe helyezi továbbá a használt termékek újra használatát, a fogyasztási láncban szereplö anyagok termelési-fogyasztási körforgásban tartását, valamint a hulladék minél nagyobb arányú anyagában történő hasznosítását. A 2013. január 1. napjától hatályos 2012. évi CLXXXV. törvényben hangsúlyozott életciklus-szemlélet alapján az életciklus értékelés (Life Cycle Assessment, LCA) eredményeit és következtetéseit megfelelő formában kell közölnünk a célközönség számára, foglalkozva az alkalmazott adatokkal, módszerekkel és feltevésekkel [3]. Az így begyüjtött hulladék utána újrahasznosításra kerülhet ahelyett, hogy szemétként pl. elégessék, ami sok szempontból sem nevezhető környezetbarátnak. A cél az újrahasznosítás, ami mellett megjegyzendő az, hogy az elmúlt évtizedben számos hulladék energetikai hasznosítási/hőkezelési technológia került előtérbe, és azokat a rendelkezésre álló legjobb technikáknak nyilvánították [4].

\section{2. Életciklus-szemlélet üveghulladék feldolgozásánál}

A bevezetésben már említésre került 2012. évi CLXXXV. hulladékgazdálkodási törvényben kiemelkedő szerepet kap az életciklus-szemlélet, amelynek keretében az életciklus elemzés (LCA) egy termék teljes életciklusát veszi figyelembe a nyersanyag kitermelésétől kiindulva a gyártáson keresztül az elhasználásán át a belőle képződő hulladék kezeléséig.

Az Életciklus értékelés (Life Cycle Assessment) lényege, hogy meg tudjuk határozni, hogy az a bizonyos termék teljes élettartama alatt - azaz az előállításától a belőle keletkezett hulladék ártalmatlanításáig - milyen környezeti terheléseket okoz, mennyi természeti erőforrást használ fel, beleértve az energiakiadásokat is. Az életciklus-értékelés alapul szolgálhat:

- $\quad$ azoknak a lehetőségeknek az azonosításához, amelyek a termékek környezeti hatását növelik az életciklusuk különbözö pontjain

- az ipari, kormányzati és nem kormányzati szervezetek döntéshozóinak tájékoztatásához (stratégiai tervezés, prioritások meghatározása, a termék vagy a folyamat tervezése, illetve újra tervezése)

- a környezeti hatások releváns mutatóinak kiválasztásához, beleértve a mérési technológiákat, és

- a marketinghez (egy ökológiai osztályozási séma kidolgozása, a környezeti igénybevétel, vagy a környezeti termék meghatározásának kifejezése) [5].

Az életciklus szakaszokon belül mindig nagyobb figyelmet szentelünk a hulladékká válás, jelen esetben az üvegcsomagolási anyagok csomagolási üveghulladékká történő válására. A termékrendszert képező csomagolási termékáramot a termékrendszer környezetvédelmi szempontjaival és hatásaival vizsgáljuk. Maga a termékrendszer olyan egységfolyamatokra osztható, amelyek a termékrendszerek termékáramai (köztes termékek és/vagy a kezelendő hulladék) által kapcsolódnak egymáshoz az elemi áramok környezet felé történő áramlásával. Az LCA egy funkcionális egység köré szerveződik (adott esetben $1 \mathrm{~kg}$ üvegtermék/üveghulladék), ahol az LCI és az LCIA összes bemenete és kimenete az adott funkcionális egységhez kapcsolódik [3].

Az 1. ábra mutatja be az LCA felépítését és részegységeinek egymáshoz való viszonyát. 


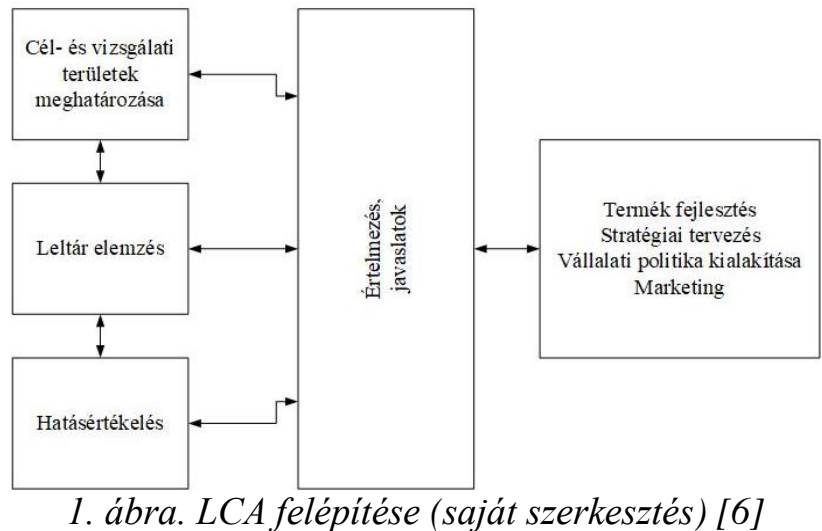

Az életciklus értékelés alapvető célja, hogy olyan technológiákat fejlesszen ki, amik hozzájárulnak a környezetünk megóvásához, egészségesebbé tételéhez, környezetbarát anyagok és segédanyagok alkalmazásához és nem utolsó sorban az emberek egészségesebbé tételéhez [7]. Minden egyes termék minden egyes életciklus szakaszában a környezetre gyakorolt hatást a GaBi szoftverben 11 környezethatási kategóriában vizsgálhatjuk és számszerüsíthetjük [8]. Az 1.táblázat a GaBi szoftverben szokásosan vizsgált 11 kategóriát ismerteti.

1. táblázat. Környezeti hatáskategóriák

\begin{tabular}{|c|c|c|}
\hline Hatáskategóriák mengevezése & Hatáskategóriák értelmezése & Egyenérték \\
\hline $\begin{array}{c}\text { Globális felmelegedési potenciál } \\
\text { (GWP) }\end{array}$ & $\begin{array}{c}\text { A különbözö üvegházhatású gázok globális felmelegedéshez } \\
\text { való hozzájárulásának a mértéke egységnyi } \mathrm{CO}_{2} \text {-hoz viszo- } \\
\text { nyítva. }\end{array}$ & $\begin{array}{l}\mathrm{kg} \mathrm{CO}_{2-}^{-} \\
\text {egyenérték }\end{array}$ \\
\hline $\begin{array}{l}\text { Savasodási potenciál } \\
\text { (AP) }\end{array}$ & $\mathrm{A} \mathrm{SO}_{2}$-hoz viszonyított savasodás. & $\begin{array}{l}\mathrm{kg} \mathrm{SO}_{2-} \\
\text { egyenérték }\end{array}$ \\
\hline $\begin{array}{l}\text { Eutrofizációs potenciál } \\
(\mathbf{E P})\end{array}$ & Az algásodás mértéke. & $\begin{array}{l}\text { kg Foszfát- } \\
\text { egyenérték }\end{array}$ \\
\hline $\begin{array}{l}\text { Humán toxicitási potenciál } \\
\text { (HTP) }\end{array}$ & $\begin{array}{l}\text { Az emberi szervezetre mérgező hatású anyagokra vonatkozó, } \\
\text { maximálisan megengedett koncentráció mértéke } 1,4 \\
\text { diklórbenzol (DCB) egyenértékben. }\end{array}$ & $\begin{array}{l}\text { kg DCB- } \\
\text { egyenérték }\end{array}$ \\
\hline $\begin{array}{l}\text { Fotokémiai ózonképződési } \\
\text { potenciál (POCP) }\end{array}$ & Az illékony szerves vegyületek ózontermelő képessége. & $\begin{array}{l}\text { kg Etilén- } \\
\text { egyenérték }\end{array}$ \\
\hline $\begin{array}{l}\text { Ózonréteg elvékonyodási } \\
\text { potenciál (ODP) }\end{array}$ & $\begin{array}{l}\text { Föként a halogénezett szénhidrogének rovására írható, refe- } \\
\text { rens összetevőként az R11 került kiválasztásra. }\end{array}$ & $\begin{array}{l}\text { kg R11- } \\
\text { egyenérték }\end{array}$ \\
\hline $\begin{array}{l}\text { Földi Öko-toxicitási potenciál } \\
\text { (TETP) }\end{array}$ & \multirow{3}{*}{ Növény és állatvilágra vonatkozó mérgező anyagok } & \multirow{3}{*}{ DCB } \\
\hline $\begin{array}{c}\text { Tengervízi Öko-toxicitási } \\
\text { potenciál (MAETP) }\end{array}$ & & \\
\hline $\begin{array}{c}\text { Édesvízi Öko-toxicitási potenciál } \\
\text { (FAETP) }\end{array}$ & & \\
\hline $\begin{array}{c}\text { Aboitikus kimerülő források } \\
\text { (ADPE) }\end{array}$ & Magába foglalja a nagyszámú fémércet. & $\begin{array}{l}\text { kg antimon- } \\
\text { egyenérték }\end{array}$ \\
\hline $\begin{array}{l}\text { Aboitikus kimerülö fosszilis } \\
\text { források (ADPF) }\end{array}$ & Magába foglalja a kimerülő fosszilis energiaforrásokat. & MJ \\
\hline
\end{tabular}


A körkörös gazdaság modellje alapvetően arra épül, hogy a termékek élettartamát meghosszabbítsuk. Jelen esetben az üvegcsomagolásnak, mint terméknek egy második esélyt adunk azzal, hogy életciklusa végén feldolgozzuk és másodlagos termékké (üveglisztté majd üveghabbá) alakítjuk át. Az üveghulladék mennyiségének csökkentése, a környezetbarát terméktervezés és az újrafeldolgozásra épülő újrafelhasználás csökkenti az üvegházhatású gázok kibocsátását, ami életciklus elemzésekkel jól ellenőrizhető. Az üvegcsomagolás életciklusa végén keletkező csomagolási üveghulladékra vonatkozó előkészítési technológiát a következő fejezetben ismertetem.

\section{3. Üveghulladék előkészítési technológiája}

Jelen cikk a háztartásokból szelektíven begyüjtött üveghulladék egy általános előkészítési technológiáját mutatja be, abból a nézőpontból, hogy a lehetőség szerint a leghatékonyabban érjük el a továbbfeldolgozáshoz - pl. üveghab alapjául szolgáló üvegliszt [9] - szükséges szemcseméretet és tisztaságot. Abból a feltételezésből indulunk ki, hogy a szelektív konténerekből kikerülő üveghulladék között nem található olyan darab, aminek bármelyik mérete nagyobb lenne, mint $300 \mathrm{~mm}$.

Az üveghulladék előkészítésének technológiai folyamatában először kisebb szemcseméretüre kell összeaprítani a konténerekbe bedobált üvegtörmeléket. Az így már a 0-125 mm közötti méretü üveg egyingás pofástöröben kerül aprításra. Az aprított üveg (töret maximális szemcsemérete: $30 \mathrm{~mm} 125$ mm-es maximális feladás esetén) osztályozásra kerül egy mágneses meghajtású szitavibrátor segítségével (rázószita), majd röpítőtörőre kerül. A $30 \mathrm{~mm}$ vagy attól kisebb szemcseméretü üveg a röpítő törő forgórészébe jut a törő beömlő nyílásán keresztül, ahol törést szenved. A röpítőtörőből távozó töretből a mágneses fémek és nem-vas fémek egy mágneses szeparátor segítségével leválasztásra kerülnek. Erre a lépésre azért van szükség, hogy az anyagáramból kiszürjük az esetlegesen bekerült fémes anyagokat, amik lehetnek például zárókupakok. Az aprított, mágneses fémektől megszabadított, osztályozott és egyenletes szemcseméretü vegyes üveg optikai válogatóra kerül, ahol a szétválasztott fehér és színes üvegfrakciók golyósmalomba kerülnek. A golyósmalomban történő örlést követően az őrlemény, azaz az üvegliszt lesz az üveghab egyik alapösszetevője. A 2. ábra mutatja be ennek a leírt elökészítési technológiának a lépéseit.

\subsection{Az elökészítési technológia főbb berendezései}

Az elökészítési technológia folyamatában a gyakorlatban több lépés is szükséges ahhoz, hogy a kívánt végterméket, jelen esetünkben az üveglisztet elérjük. Jelen cikkben a legföbb berendezések (aprító- és örlőberendezések, mágneses szeparátor és optikai válogató) bemutatása történik. Azokra a berendezésekre térünk ki részletesen, amelyek kulcsfontosságúak ahhoz, hogy a csomagolási üveghulladék a körkörös gazdasági elv alapján ne végtermék legyen, hanem egy új termék alapanyaga.

\subsubsection{Pofástörö}

Az egyingás pofástörőket föleg rideg, kemény anyagok - mint pl. az üveg - aprítására használják. Müködési elve, hogy gördülőcsapágyazású excenter tengelyen ágyazott és a biztonsági törölappal megtámasztott inga mozgatásával történik az aprítás. A kijövő szemcseméretet a kiömlőrést beállító csavarorsós ékemelő szerkezet biztosítja.

Az egyingás pofástörők, maximum $3000 \mathrm{kp} / \mathrm{cm}^{2}$ törőszilárdságú, kemény, koptató, rideg anyagok, kőzetek, ércek durva- és közép aprítására szolgálnak. A hulladék előkészítésben elsősorban üveg, beton, tégla durva $(\mathrm{x}>50 \mathrm{~mm})$ aprítására alkalmas. 


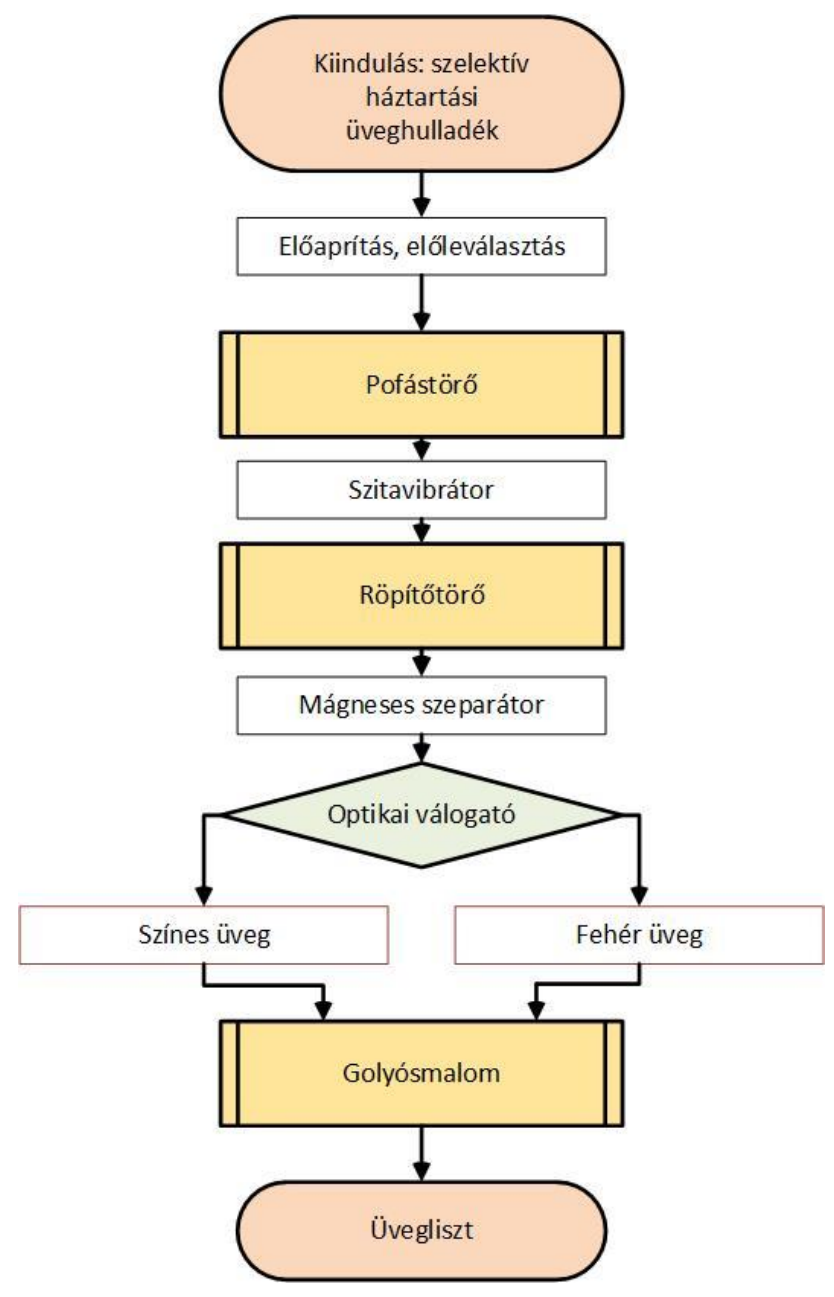

\section{2. ábra. Az üveghulladék elökészitési folyamatábrája}

Egylépcsős és kétlépcsős üzemekben is alkalmazható, 4-9 közötti aprítási fokkal és 0,2-0,7 kWh/t értékü fajlagos munkaszükséglettel. A feladás szemcseméretét a garatnyílás mérete határozza meg. A töret szemcseméretét az állítható résméret (kiömlő rés mérete) határozza meg. A pofástörőknek két meredek, alul hegyesszöget (törőszög: $15-18^{\circ}$ ) bezáró törőfelületük van, ahol az egyik törőfelület áll, a másik ehhez közeledik és távolodik, megfelelő löketszámmal. Gördülőcsapágyazású excentertengelyen ágyazott és biztonsági törőlappal megtámasztott inga mozgatásával történik az aprítás, lassan fokozódó nyomással. A törőfelületek ék alakú bordázása következtében a nyomás mellett hajlító és vágó (hasító) igénybevételek is fellépnek. Az egyenletes járás biztosítására az excentertengely két végére lendkerék van felszerelve. Ezek közül az egyik ékszíjtárcsának van kiképezve a hajtás számára. A kiömlőrés és a töret méretének változtatása csavarorsós ékemelő szerkezettel történik. Az egyrészü törőház és az inga acélöntvényből, a törőpofák pedig kopásálló, nagy mangántartalmú acélöntvényből készülnek. [13]

A 3. ábra mutatja be a pofástörő vázlatos rajzát és föbb technikai paramétereit. 


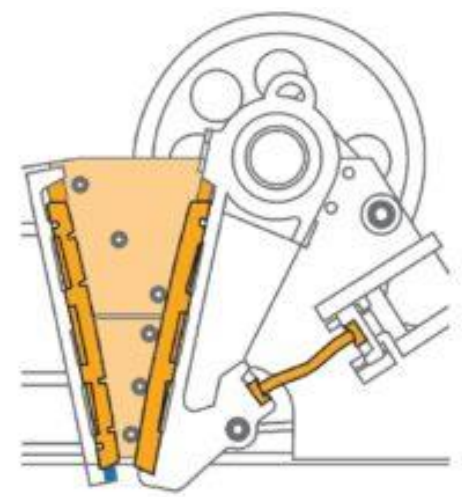

3. ábra. Pofástörö vázlatos rajza [12]

\subsubsection{Röpítőtörő}

A röpítőtörők az anyagszemcsék kinetikus energiáját hasznosítják aprítási munkára az ütköző hatást kihasználva. Az első szemcseméret csökkenést a feladott szemcséknek a nagy kerületi sebességgel forgó rotor védőléceinek történő ütközése okozza, majd második lépésben az álló ôrlőpályának ütközve aprózódik tovább. Innen visszakerül a töret a verőlécekre és ez a folyamat addig ismétlődik, amíg a töret a megfelelő szemcseméretet el nem éri. Ezt a müködési elvet mutatja be a 4. ábra. A röpítőtörők kis- és közepes szilárdságú rideg anyagok durva-, közép- és finom aprítására alkalmas berendezések. Kemény rideg anyagok aprítására is alkalmas, a kalapácstörőkkel ellentétben. A hulladék előkészítésben elsősorban üveg, beton, tégla, aszfalt és beton durva $(\mathrm{x}>50 \mathrm{~mm})$ és közép $(\mathrm{x}=5-50 \mathrm{~mm})$ aprítására alkalmas. Egylépcsős és kétlépcsős üzemekben is alkalmazható, nagy aprítási fokkal és kedvező fajlagos munkaszükséglettel (aprítási munka: 0,4-7 kWh/t). A feladás szemcseméretét a garatnyílás mérete határozza meg. A töret szemcseméretét a rotor kerületi sebessége, illetve a rotor dobóléceinek és az ütközőlemezek közötti távolság határozza meg. A töret szemcséi jó kubicitással rendelkeznek, kevés túlméretes szemcse található a töretben általában. [14]

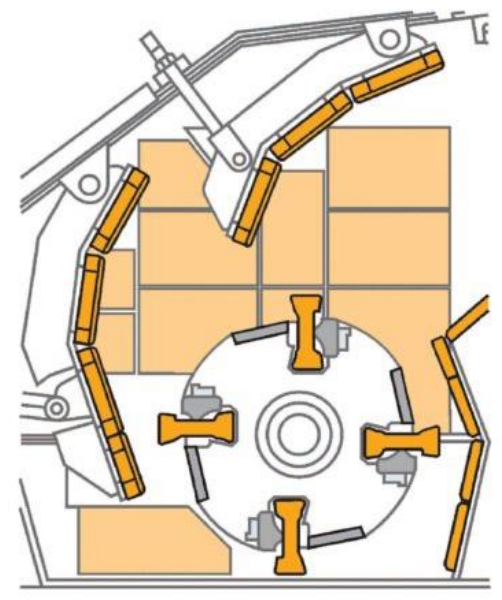

4.ábra. Röpitőtörö vázlatos rajza [12] 


\subsubsection{Mágneses szeparátor}

Nagyon fontos lépés, hogy az anyagáramból kiszürjük az esetlegesen bekerült fémes anyagokat, gondolni kell itt például a szelektív gyüjtőkonténerbe az italos üvegekkel együtt bekerült zárókupakokra. Ezek leválasztásának az egyik elterjedt megoldása a mágneses szalagszeparátor, aminek vázlatos rajza látható az 5. ábrán. [10]



5. ábra. Mágneses szeparátor vázlatos rajza [14]

\subsubsection{Optikai válogató}

Miután az anyagáramunkból eltávolítottuk az idegen anyagokat, jöhet a szín szerinti, úgynevezett optikai válogatás, amely során a vegyes üveghulladék áramból leválasztjuk a fehér üveghulladékot. Ennek az eljárásnak az egyik lehetséges módját mutatja be a 6 . ábra.

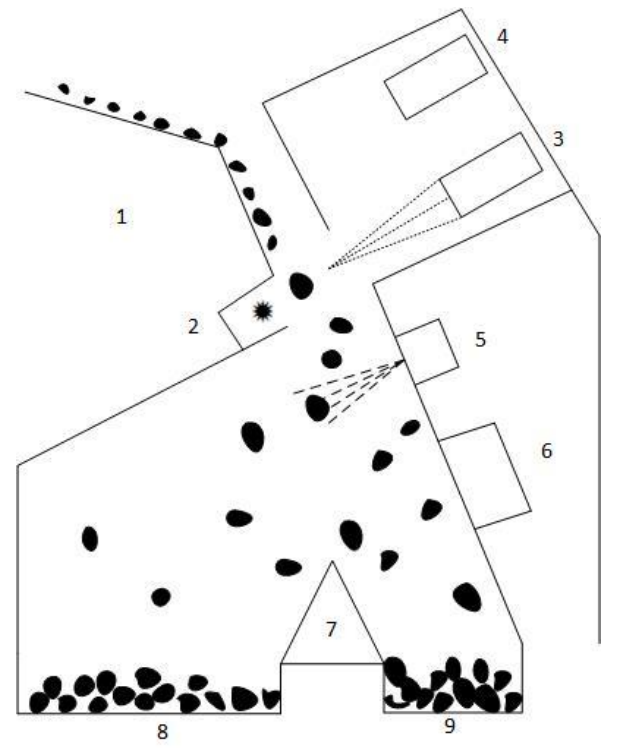

Jelölések:

1. Csúszda

2. Világítás

3. CCD sorkamera

4. Képfeldolgozás

5. Kifúvó rendszer

6. Szelepvezérlés

7. Elválasztó pajzs

8. Szennyezö anyag

9. Megtisztított anyag

6. ábra. Optikai válogató vázlatos rajza (saját szerkesztés) 
Az 1-es számmal jelölt vibrációs csúszdán érkező anyagáram egy ferde csúszdán felgyorsul és elválasztásra kerül. Az elválasztott részecskék a 2-es számmal jelölt világító sor mellett leesnek, ahol a fehér fény által átvilágításra kerülnek. Ezt a fehér fényt a leeső részecskék színüknek megfelelően megszürik. A részecskék a 3-as számmal jelölt sorkamerához kerülnek. A fény itt piros, zöld és kék alapszíneire bontódik fel. A képfeldolgozás - 4-es szám az ábrán - folyamán az osztályozás jó vagy hibás színosztályokra történik. A hibás színek egy levegő impulzus - 5-ös részegység - által kifúvásra kerülnek. Ehhez a képkiértékelés egy jelet küld a szelepvezérlésnek (6), ami megfelelő, időben késedelemmel bekapcsol egy szelepet úgy, hogy az anyagáramból a részecske eltávolításra kerül. [15]

\subsubsection{Golyósmalom}

Az optikai válogató után keletkezett egyszínủ, tiszta üveghulladék anyagáram egy újabb szemcseméret csökkentő berendezésen kerül átvezetésre. Az őrlés során az osztályozott üveghulladékot kisebb szemcseméretűvé finomítjuk, amelynek végeredményeként $1 \mathrm{~mm}$ alatti átlagos szemcseméretü terméket kapunk. Kulcsfontosságú lépést jelent az üveg finom őrlése. Az örlésnél a leggyakrabban alkalmazott berendezés a golyósmalom, aminek müködéi elvét mutatja be a 7. ábra. Kemény és lágy anyagok, száraz és nedves örlésre egyaránt alkalmas, nagyteljesítményủ gépek [11]. Az őrlőtér vízszintes tengely körül forgó hengeres és kúpos részekből álló acélköpeny, amelyet belülröl páncélzattal védenek a kopástól. Az aprítást szabadon mozgó őrlőgolyók végzik ütéssel, nyomással, ütközéssel, dörzsöléssel. A nyakcsapágyakon feltámasztott malomtestet fogaskerék-koszorún át hajtják. Az örlőteret gyakran válaszfalakkal kamrákra osztják, így az őrlési finomság előrehaladtával a legmegfelelőbb nagyságú és alakú örlőtesteket alkalmazhatják. Az őrlőmalom aprítási fokát és a fajlagos őrlési munkát a feladásra kerülő, őrlendő anyag és az őrlemény $80 \%$-os szemcsemérete (a feladás és az őrlési finomság) határozza meg [16]. Manapság már bebizonyosodott, hogy az őrlés a részecskeméret csökkentése mellett szerkezeti és kémiai változásokat okoz az őrlőanyagban is. Az őrlési folyamat irányítható az elsődleges mechanokémiai folyamatok elősegítésével és a másodlagos folyamatok csökkentésével [17].

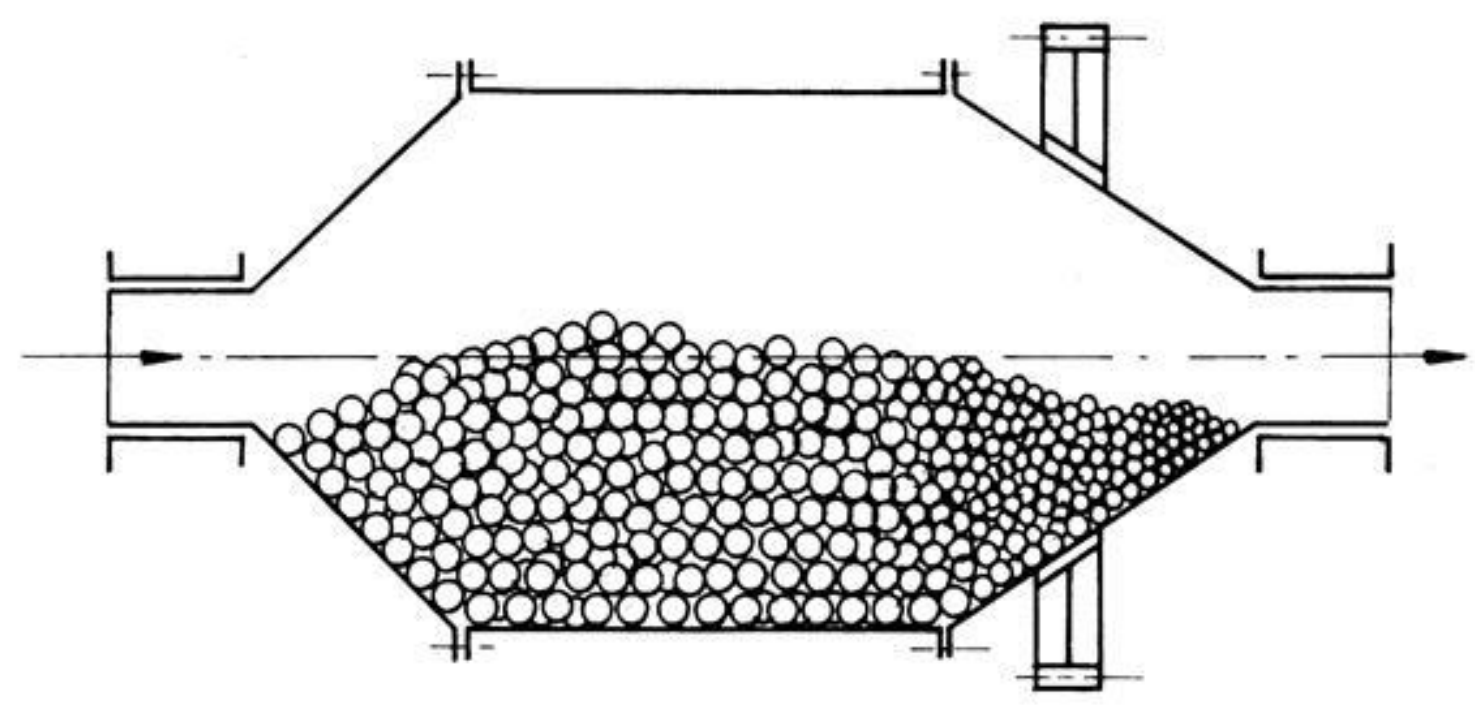

7. ábra. Golyósmalom vázlatos rajza 


\section{4. Összefoglalás}

A cikkben meghatározott technológia azt a célt szolgálja, hogy a körkörös gazdaság érdekében a szelektív begyüjtésből származó háztartási üveghulladék visszakerüljön a körforgásba, mint üvegliszt, ami felhasználható a jelenleg egyre inkább - föképpen az építőiparban - használatos üveghab alapjául. Az üveghab egyre inkább terjedő felhasználásának a hátterében a viszonylag nagy szilárdsága és kis sürüség áll. Az üveghab többféle üveg alapanyagból is készülhet [9], nemcsak háztartási üveghulladékból, de a környezetünk megóvása érdekében szorgalmazni kell azon technológiákat, amikkel a háztartásokban keletkezö öblösüveg (ide tartoznak a beföttes üvegek, üdítős-, sörös-, boros-, pezsgösés egyéb italos üvegek, az étkezési olajok üvegei, stb.) további feldolgozásra kerül. Ilyen technológia a cikkben bemutatott eljárás is, amivel az üveghulladékból üveglisztet kapunk.

\section{Irodalom}

[1] Mannheim V., Fehér Zs., Siménfalvi Z.: Innovative solutions for the building industry to improve sustainability performance with Life Cycle Assessment modelling. In Solutions for Sustainable Development; Taylor \& Francis Group: Milton Park, UK, 2019. https://doi.org/10.1201/9780367824037-31

[2] EUR-Lex: https://eur-lex.europa.eu/legal-content/HU/TXT/PDF/?uri=CELEX:32018L0852\&from=HU

[3] Mannheim V.: Examination of Thermic Treatment and Biogas Processes by LCA. Annals of Faculty Engineering Hunedoara - International Journal of Engineering 2014, 12:225-234

[4] Mannheim V., Siménfalvi Z.: Determining a priority order between thermic utilization processes for organic industrial waste with LCA. Waste Management and the Environment VI. WIT Transactions on Ecology and the Environment 2012, 163:153-166 https://doi.org/10.2495/WM120151

[5] https://denkstatt.eu/szolgaltatasaink/eletciklus-elemzes/?lang=hu

[6] Nigri E.M., de Barros A.C., Rocha S.D.F., Filho E.R.: Assessing environmental impacts using a comparative LCA of industrial and artisanal production processes: "Minas Cheese" case, Food Sci. Technol 2014, 34(3):522-531 https://dx.doi.org/10.1590/1678-457X.6356

[7] Piotrowska K., Kruszelnicka W., Bałdowska-Witos P., Kasner R., Rudnicki J., Tomporowski A., Flizikowski J., Opielak M.: Assessment of the Environmental Impact of a Car Tire throughout Its Lifecycle Using the LCA Method, Materials 2019, 24(12):4177 https://doi.org/10.3390/ma12244177

[8] Szücs E., Budai I., Matkó A.: Környezetmenedzsment, https://www.tankonyvtar.hu/hu/tartalom/tamop425/0021_Kornyezetmenedzsment/0021_Kornye zetmenedzsment.pdf

[9] Simon A., Voith K., Mannheim V.: Investigation of different foam glasses with Life Cycle Assessment method, Solutions for Sustainable Development - Szita, Jármai \& Voith (eds.) (C) 2020 Taylor \& Francis Group, London, ISBN 978-0-367-42425-1

[10] Nagy B.: Kommunális gépek I., Digitális tankönyvtár: Környezetvédelem, https://regi.tankonyvtar.hu/hu/tartalom/tamop412A/20100019_Kommunalis_gepek_I/ch06.html

[11] https://www.tankonyvtar.hu/en/tartalom/tamop425/2011_0001_519_44580_Vegyipari_Muvelet $\tan / \mathrm{ch} 02 \mathrm{~s} 06 . \mathrm{html}$ 
[12] https://vbpartner.hu/termek/ropito-toro-alkatreszek/

[13] http://www.petrik.hu/files/Tananyagtar/Bertalan\%20Zsolt/Vegyipari_muveletek_2uj.pdf

[14] https://docplayer.hu/7441979-6-betontechnologiai-gepek-i.html

[15] file:///C:/Users/Katalin/Downloads/A_bekescsabai_hulladekvalogato_bemutatasa.pdf

[16] Mannheim V., Siménfalvi Z.: Determination of Power Consumption for Suspension Mixing in Stirring Equipments and Stirred Ball Mills. Journal of Materials Science and Engineering 2012, 7:572-578

[17] Mannheim V.: Empirical and scale-up modeling in stirred ball mills. Chemical Engineering Research and Design 2011, 89(4):405-409 https://doi.org/10.1016/j.cherd.2010.08.002 